Document de Recherche du Laboratoire d'Économie d'Orléans

DR LEO 2015-23

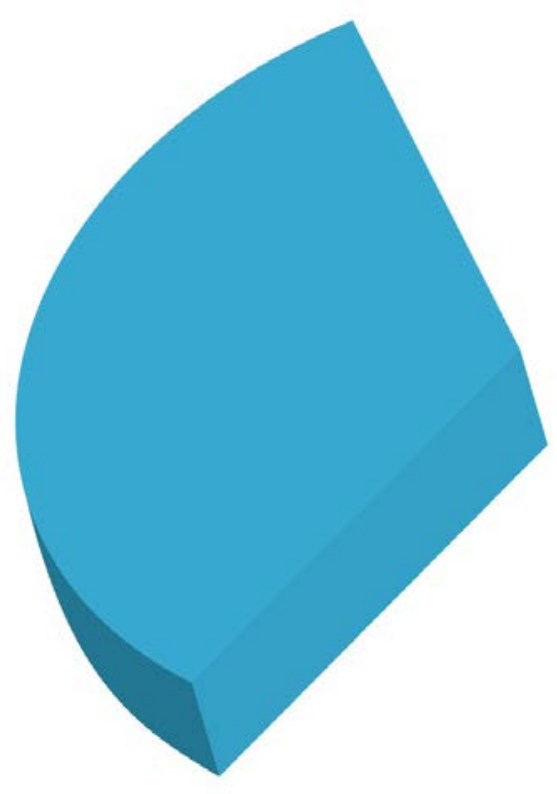

Does FDI Crowd out Domestic Investment in Transition Countries?

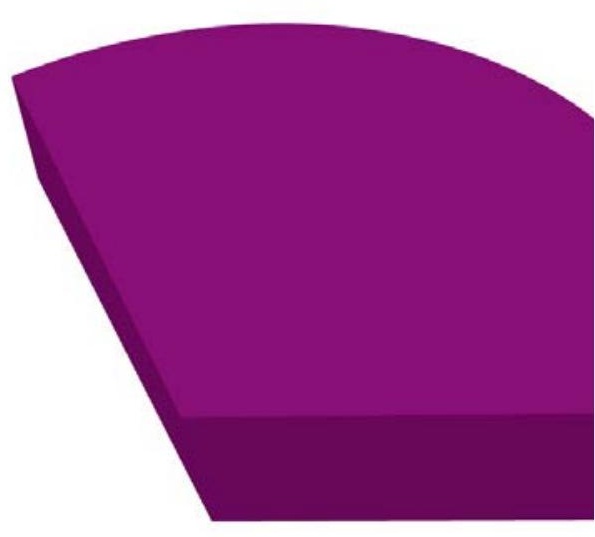

Cristina JUDE

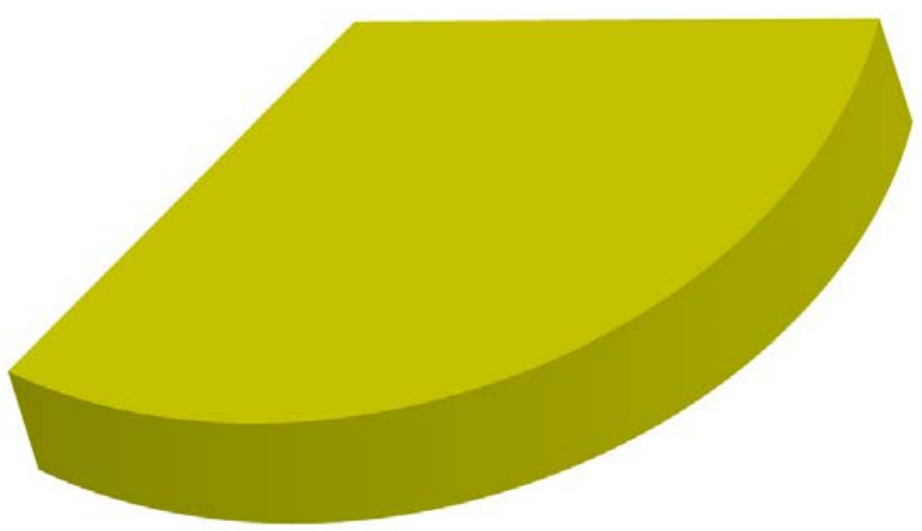




\title{
Does FDI crowd out domestic investment in transition countries?*
}

\author{
Cristina Jude ${ }^{\dagger}$ \\ Banque de France \\ and \\ Laboratoire d'economie d'Orléans, France
}

December 2015

\begin{abstract}
The aim of this paper is to empirically test the hypothesis of FDI led capital accumulation in Central and Eastern European countries. More precisely, we investigate the relationship between FDI and local investment, using a sample of 10 CEEC over the period 1990-2010. We find FDI to crowd out domestic investment, while the effect decreases with time. Our results also indicate that greenfield FDI may develop long run complementarities with domestic investment, while mergers and acquisitions do not prove any significant effect on domestic investment. Finally, financial development seems to foster a certain crowding-in effect in the case of mergers\&acquisitions.
\end{abstract}

Key words: investment, FDI, crowding-out, economic transition, financial development

JEL codes: E22, F21, F43, O52

\footnotetext{
* The author would like to thank Gabor Hunya and the members of the Vienna Institute for International Economics Studies (WIIW) for useful comments on this paper. The views expressed herein are those of the authors and do not necessarily reflect those of institutions they belong to. Any errors or omissions remain our sole responsibility.

${ }^{\dagger}$ Banque de France, DGEI 49-1488, 75049 Paris and Univ. Orléans, CNRS, LEO, UMR 7322, F-45067 Orléans, France. Tel.: +33 14297 77 35, Email : cristina.jude@banque-france.fr / cristina.jude@univ-orleans.fr
} 


\section{Introduction}

According to the neoclassical growth theory (Solow, 1956), economic growth is mostly driven by capital accumulation, up to the optimum level of capital stock per worker (although convergence can actually last for a very long time). In the perspective of investment as a key determinant of economic growth, international capital flows, essentially FDI, can usefully complement domestic capital supply, thus facilitating financing for local investment projects.

FDI does not only add to the existing capital stock, but can also influence the structure of the capital stock itself. Typically, local investors may react to increased FDI inflows, leading to either a substitution or a complementary relationship (Agosin and Machado, 2005). Foreign investors may crowd-out local investors due to increased competitive pressure, and thus deter previously planned investment projects (Markusen and Venables, 1999). Additionally, FDI may also increase demand addressed to local suppliers and thus have a beneficial crowding-in effect on domestic investment (Cardoso and Dornbusch, 1989). Finally, the supply of funds associated with FDI can increase local liquidity and loosen financial constraints for domestic investment (Harrison et al. 2004). The reaction of local investors to the entry of foreign investors is thus of major interest for policy makers, in order to maximize domestic investment rates. If FDI is found to significantly crowd out domestic investment, its benefits for developing countries could be seriously challenged and policies designed to attract FDI could be put into question.

FDI can be seen through a double perspective: that of a financial flow and that of a knowledge flow accompanying capital ${ }^{3}$. This paper positions itself in the first perspective, where the effects of FDI can mainly be found in capital stock accumulation. We thus investigate the contribution of FDI to capital accumulation in host countries, essentially through the interaction with domestic investment. More precisely, we seek to identify whether FDI stimulates or discourages domestic investment in CEEC.

The question of FDI effect on capital accumulation seems all the more important in Central and Eastern European countries (CEEC), disposing of an obsolete capital stock inherited from the socialist era. Given the initial distance to the world technological frontier, there were even

\footnotetext{
${ }^{3}$ The second perspective is much more present in the literature, with numerous papers investigating the technology transfer associated with FDI and the corresponding contribution to economic growth (de Mello, 1997; Carkovic and Levine, 2005; Liu, 2008; Jude, 2015).
} 
opinions stating that the contribution of FDI to capital accumulation in CEE was more growth enhancing than the introduction of new technologies (Hunya, 2000; Eichengreen, 2004).

Our contribution to the literature can be summarized as follows. First, we depart from the traditional empirical framework used in previous studies to adopt a broader approach that includes additional determinants of investment, virtually ignored in the literature. Second, we investigate the individual effects of greenfield FDI and mergers and acquisitions (M\&A), as we expect potentially different implications for the dynamics of local investment. Third, we built on the idea of a two nature interaction between FDI and domestic investment, through both the real and the financial market, and thus we tackle the role of financial development in favoring a crowding-in of domestic investment. This is, to the best of our knowledge, the first paper to provide some indication on the relative importance of the two interaction channels, all the more through the perspective of the different types of FDI. Finally, we focus our analysis on CEEC, with a particular stake in the capital accumulation issue, analyzing the entire period after the fall of communism.

Our results indicate that FDI generally crowds out domestic investment. While the crowdingout decreases with time, it does not lead to an overall complementarity relationship. We find the interaction between greenfield FDI and domestic investment to mainly occur through a real market mechanism, while for M\&A the interaction occurs only through the financial market. Though greenfield FDI preserves a negative short run effect on domestic investment, it allows for a long run complementarity. M\&A, tributary to their financial status, do not prove any significant effect on capital accumulation. Nevertheless, a certain degree of financial development can favor a crowding in effect of M\&A on domestic investment.

In an attempt to shed some light on the issue of substitution/complementarity between foreign and domestic investment, our paper is organized as follows. Section 2 recalls the mechanisms of such an interaction and surveys the existing literature. Section 3 lays out the empirical methodology and the data being used. The main results are then presented in section 4, together with a discussion on the different types of FDI. Section 5 investigates the role of financial development in fostering a crowding-in effect of FDI on domestic investment. Finally, section 6 highlights the main conclusions. 


\section{Literature review}

From the perspective of FDI as a capital flow, its effects on the host economy can mainly be found in capital accumulation ${ }^{4}$. The literature thus identifies two main interaction channels between FDI and domestic investment (UNCTAD, 1999; Agosin and Machado, 2005).

A first mechanism concerns the interaction on the real market, where the entry of FDI affects the demand addressed to local firms. As foreign affiliates often have lower marginal costs due to their specific advantage (Aitken and Harrison, 1999), they capture a part of the domestic demand, forcing local firms to reduce output and thus raise their average cost. Moreover, increased competition may eventually lead them to abandon investment projects or even reduce existing production capacities. Nevertheless, sufficiently competitive local firms may respond to FDI entry by increasing and updating their capital stock (De Mello, 1999). To the extent that FDI use local inputs, investment by domestic suppliers in upstream sectors can be stimulated as well (Cardoso and Dornbusch, 1989). Finally, funds temporally released could be directed to other activities where local firms have a comparative advantage.

A second mechanism originates on the financial market, where FDI may improve access to finance for domestic firms. As an international capital flow, FDI increases local liquidity, favors currency appreciation and interest rates decrease (Harrison et al., 2004). If the effect seems more important in developing countries (Harrison et al., 2004), its extent depends on the degree of financial market development (Razin et al. 1999).

Finally, domestic investment can also take advantage of "collateral benefits" associated with FDI (Kose et al, 2006). Macroeconomic conditions for attracting FDI, such as economic stability, institutional development, a sound business environment or improved infrastructure also support local investment. Other collateral benefits include technological spillovers, the mobility of qualified labor force or the creation of potential agglomeration economies, which attract more foreign investors (Markusen and Venables, 1999).

Although the literature on FDI is extremely abundant, the interaction between FDI and domestic investment has received surprisingly little attention so far. Theoretical studies are small in number and empirical applications provide different conclusions.

\footnotetext{
${ }^{4}$ While technology spillovers associated with FDI are equally important, they are not the focus of this paper.
} 
The theoretical model of Markusen and Venables (1999) sets out a two sector economy model, with multinational companies entering the final goods sector. As a consequence, local firms in this sector are negatively affected, while firms in the intermediate goods sector are stimulated through upstream externalities. A similar study carried out by Barrios et al. (2005) shows that short term crowding-out effects within the sector can be offset by boosting demand for the upstream sector in the long run. Additionally, Backer (2002) models a labor market crowding-out effect, as he analyzes the behavior of local entrepreneurs following the entry of multinationals on the local market. He argues that a significant part of potential entrepreneurs decide to become employees of foreign affiliates rather than developing their own business. Finally, Agosin and Machado (2005) provide a simple and straight forward theoretical framework, based on the idea that foreign affiliates in developing countries introduce new products, both for the domestic and external market, with a positive effect on capital formation through upstream and downstream spillovers, in line with the endogenous growth model of Romer (1993). Nevertheless, in order to hope for an overall crowding-in effect, Agosin and Machado (2005) state that the sectoral pattern of FDI inflows should be different from the existing productive stock of host countries.

The empirical issue was until recently only marginally addressed in studies dealing with the growth effects of FDI (Borenzstein et al., 1998; Blonigen and Wang, 2004). These earlier studies concluded that the main benefit of FDI does not consist of accumulation of capital, but rather of technology transfer. Also, the crowding-out effect was thought to exist only in developed countries (Blonigen and Wang, 2004).

While investigating the role of more general international capital flows in stimulating investment in developing countries, Bostworth and Collins (1999) highlight a short-term crowding-out effect from FDI, while portfolio flows do not contribute in any way to capital formation. However, Mody and Mushid (2005) resume the previous study and show that FDI may stimulate local investment in the long run. In the case of CEEC, Mileva (2008) shows that FDI stimulates domestic investment only in countries with weak institutional development and underdeveloped financial markets.

A small number of recent empirical studies deal with the specific role of FDI in domestic capital formation, essentially based on the theoretical framework outlined by Agosin and Machado (2005), with local investment as a function of present and past values of FDI and 
output growth. While testing their model on a panel of 36 developing countries from Asia, Africa and Latin America for the period 1971-2000, Agosin and Machado (2005) fail to find a general conclusion on the effect of FDI on domestic investment. Wang (2010) and Morrissey and Udomkerdmongkol (2012) thus use large samples of around 50 countries and conclude that FDI crowds-out domestic investment. Wang (2010) also calculates a cumulative effect, indicating that the crowding-out phenomenon would disappear after approximately three years from FDI entry. Additionally, Morrissey and Udomkerdmongkol (2012) monitor the influence of political regime and economic governance on the relationship between FDI and local investment. Their confirm that countries with better governance enjoy more local investment, but suffer from a stronger crowding-out effect from FDI. On the contrary, a recent study by Farla et al. (2014) using the same dataset actually reaches the opposite conclusion. By improving the domestic investment proxy used by Morrissey and Udomkerdmongkol (2012) and refining their estimation methodology, Farla et al. (2014) conclude in favor of a crowding in effect.

We can thus notice that the empirical results are quite mitigated, depending on sample selection and the methodology used for empirical estimation. However, a certain consensus seems to emerge concerning a crowding-out effect. In the next section we will conduct an improved and detailed empirical analysis in order to test the role of FDI in capital accumulation.

\section{Methodology and data}

\subsection{Empirical methodology}

The purpose of this section is to empirically estimate the influence of FDI on domestic capital accumulation. More specifically, we seek to investigate whether FDI develops a crowding-in or a crowding-out effect on domestic investment. To this end, we estimate various specifications of an augmented investment function, including FDI flows as explanatory variable. We consider investment to be a partial adjustment process, between the existing and the desired capital stock, in the context of liquidity constraints and time adjustment constraints. Moreover, as investment is a structural component of the economy, we expect it to show a strong autoregressive behavior. We thus first introduce in our empirical equation lagged investment $\left(I_{i, t-1}\right)$. This variable allows us to take into account the persistence of 
the investment rate and also to highlight the dynamic nature of the investment framework by calculating long-term coefficients. Building on the empirical framework of Mody and Murshid (2005), we thus estimate the following investment function:

$$
I_{i t}=f\left(I_{i t-1}, G R O W T H_{i t-1}, I N T E R E S T_{i t}, F D I_{i t}, K_{i t}, X_{i t}\right)
$$

Among the classical determinants of investment, we include lagged real GDP growth ${ }^{5}$ $\left(G R O W T H_{i, t-1}\right)$, as a proxy for the accelerator effect, and the real interest rate (INTEREST $\left.T_{i t}\right)$ as a proxy for the cost of capital ${ }^{6}$. Contrary to most studies that use short-term interest rates, we consider in our equation the long-term interest, corrected by the GDP deflator. FDI represents foreign direct investment flows while $K_{i t}$ is a vector of capital flows other than FDI, both expressed as a share of GDP. $K_{i t}$ comprises essentially portfolio investment (PORTF) and bank loans (LOANS). This will allow us to compare the influences of three types of international capital flows on domestic investment. The literature identifies several advantages of FDI flows compared to portfolio and bank loans, especially their long-term commitment, which makes them more stable and less volatile to market fluctuations and global financial conditions. $X_{\text {it }}$ is a vector of control variables. The literature (UNCTAD, 1999, 2003) identifies mainly the terms of trade, economic uncertainty and financial liquidity as additional determinants of investment.

We use changes in the terms of trade (TERMS_TRADE) as a proxy for the relative price of imported capital goods. An increase in the terms of trade indicates a higher purchasing power of the export revenue. A country can thus import more for the same volume of exports, with a potentially positive effect on investment through higher imports of capital goods ${ }^{7}$. We measure uncertainty through inflation volatility (VOLAT), computed as the coefficient of variation of the annual inflation rate. We thus consider the lack of predictability and the frequent variations to discourage investment more than a consistently high level of inflation.

As a proxy for financial liquidity, we use the deviation of the M2 monetary aggregate from its three-year moving average (DEV_M2), as Mody and Murshid (2005) and Mileva (2008). We

\footnotetext{
${ }^{5}$ Lagged GDP growth is justified by expectations, adjustment and hysteresis phenomena in economic variables.

6 The empirical specification of Agosin and Machado (2005), though followed by many authors (Misun and Tomšík, 2002; Kumar and Pradhan, 2002), considerably restrains the determinants of local investment. One of the key determinants missing is the cost of capital, as authors state that the interest rate is not significant factor in explaining investment in developing countries. We believe, however, that in countries in CEE, emerging rather than in developing countries, access to credit could be an important factor explaining investment.

${ }^{7}$ However, if imports contain mainly consumer goods, the effect on capital accumulation becomes insignificant.
} 
expect an increase in this indicator to have a positive contribution to gross capital formation, facilitating access to local funding of investment projects. Moreover, to the control variable already identified by the literature, we add changes in labor productivity $(W)$ and the degree of trade openness (TRADE_OPEN). Productivity growth may be a factor favoring investment, as it provides information about the quality and the efficiency of labor inputs. Additionally, a high degree of trade openness is expected to encourage investment, especially in export oriented sectors. Additionally, we considered several other determinants of investment, which proved to be insignificant (aggregate profitability, the price of capital goods, currency depreciation, public subsidies and the level of taxation). Finally, we add the time trend in order cu catch business cycles common to CEE countries ${ }^{8}$. Therefore, the empirical equation we will estimate is the following:

$$
I_{i t}=\alpha I_{i t-1}+\beta_{1} G R O W T H_{i t-1}+\beta_{2} \text { INTEREST }_{i t}+\beta_{3} \text { FDI }_{i t}+\beta_{4} K_{i t}+\beta_{5} X_{i t}+v_{i}+t+\varepsilon_{i t}
$$

With $i=1,2, \ldots, 10$ referring to the 10 countries considered, and time horizon $t$ spans from1990 to 2010. $v_{i}$ are country-specific fixed effects, and $\varepsilon_{i t}$ is the error term, uncorrelated over time and across countries.

Finally, what we are interested in when looking at the FDI coefficient in equation (2) is not a positive value, but rather its comparison to 1 (Agosin and Machado, Mody and Murshid, 2005). If a substitution effect takes place (crowding-out), gross fixed capital formation will grow less than the increase in FDI, which should lead to an FDI coefficient less than 1. Adversely, in the case of a complementary effect (crowding-in), the increase in gross fixed capital formation will be higher than the increase in FDI, leading to a coefficient higher than 1. Markusen and Venables (1999) actually suggest a two stage impact of FDI on domestic investment: an initial crowding-out effect, followed by a long-term crowding-in effect. This phenomenon might be related to the concept of creative destruction, set out by Aghion et al. (2009), though in a different context. When combining the two time horizons, we identify four possible scenarios, which we will seek to validate in our empirical analysis. These are as follows:

\footnotetext{
${ }^{8}$ We do not include time dummy as our relatively long time series (21 years) would significantly multiplies the number of instruments.
} 
Table 1. Research hypothesis on FDI and domestic investment

\begin{tabular}{|l|c|c|l|}
\hline & Short term effet & Long term effet & Overall impact \\
\hline$H 1$ & $\beta_{\mathrm{S}}<1$ & $\beta_{\mathrm{L}}<1$ & Crowding-out \\
\hline$H 2$ & $\beta_{\mathrm{S}}<1$ & $\beta_{\mathrm{L}}>1$ & Creative distruction \\
\hline$H 3$ & $\beta_{\mathrm{S}}>1$ & $\beta_{\mathrm{L}}<1$ & Temporary crowding-in \\
\hline H4 & $\beta_{\mathrm{S}}>1$ & $\beta_{\mathrm{L}}>1$ & Crowding-in \\
\hline
\end{tabular}

Note: There is always the possibility for long-term elasticity to be null, when the four hypothesis are reduced to only two, crowding-out and crowding-in.

The dynamic nature of equation (2) imposes its estimation through the general method of moments GMM (Arellano and Bond, 1991; Arellano and Bover, 1995). We thus instrument lagged investment by its own past values, in order to correct the endogeneity specific to dynamic equations. As preliminary tests showed a high persistence in the investment variable, we chose to go forward with Arellano and Bover (1995) GMM estimator ${ }^{9}$. This estimator uses orthogonal deviations instead of first order differences in order to remove the fixed effect. Besides it recommendation for persistent time series, the estimation also presents the advantage of preserving sample size, contrary to the first difference transformation. Moreover, Hayakawa (2009) showed by means of Monte Carlo simulations that the orthogonal deviations GMM estimator has better performance than the first difference one. Due to our small sample size, we are extremely careful to the number of instruments we use, in order to preserve the validity of the Sargan over-identification test. We thus limit the number of instruments to the second of lag of the dependent variable. $X$

Additionally, causality may run in both directions between international capital flows and local investment. A high local investment rate may signal profitability opportunities and favorable business climate, therefore encouraging the entry of foreign investors (Mody and Murshid, 2005). We test the need of instrumenting capital flows by using the DavidsonMacKinnon exogeneity test. Results confirm the presence of endogeneity between capital flows and local investment (Table 8 in appendix). Consequently, in addition to the lagged dependent variable, we also instrument FDI, PORTF and LOANS by their lagged levels ${ }^{10}$.

\footnotetext{
${ }^{9}$ Arellano and Bover (1995) showed that the GMM estimator does not depend on the chosen transformation to eliminate fixed effects (differences or orthogonal deviations), provided that all available instruments to be used.

${ }^{10}$ If the case of endogenous explanatory variables, the first lag of the variable is a valid instrument, there is no need to start the instrument set at lag 2.
} 
Finally, as variables in levels are not very good instruments for the transformed equation through GMM, we search for external instruments (not included in the baseline equation) in order to isolate the exogenous component of capital flows. Although in the original specification of Arellano and Bond (1991), all instruments were internal, the efficiency of estimates significantly increases when introducing external instruments. These instruments need to be correlated with capital flows, but exogenous to the dependent variable. We thus test several potential external instruments, namely: regional capital flows as a share of regional GDP, financial openness, the U.S. interest rate and the exchange rate volatility. Their poor correlation with the investment is shown in Table 9 in appendix, while Table 10 presents the difference in the Sargan test, indicating that regional flows and volatility as useful instruments for capital flows. Finally, we keep the exchange rate volatility as an external instrument, as it contributes the most to eliminating endogeneity in equation (2).

\subsection{Data}

The relationship between FDI and gross fixed capital formation is far from deterministic. We keep in mind that FDI is a financial flow stemming from the balance of payments, while gross capital formation is a national accounts variable. As a consequence and contrary to common belief, FDI does not measure actual investment spending by foreign firms. While multinational companies can access other financing sources for their investment projects (eg internal or external loans), a part of the FDI flows does not immediately turn into capital formation (eg. mergers and acquisitions).

Variables names and description, together with the data sources are presented into detail in the Appendix. Most data comes from the World Bank, the World Development Indicators 2012, IMF The International Financial Statistics 2012, UNCTAD, Eurostat and WIIW. The period we consider for our empirical analysis is 1990-2010, while the countries selected are Bulgaria, Czech Republic, Estonia, Hungary, Latvia, Lithuania, Poland, Romania, Slovakia, Slovenia. The database is therefore structured as an unbalanced panel with 10 countries and 21 years. The number of observations may vary among the different empirical specifications, due to the lack of observations at the certain variables. Table 7 in appendix summarizes the descriptive statistics of the main variables used. 
Compared to portfolio investment and foreign bank loans, FDI is definitely expected to play a higher role in CEE economies, given its share in GDP and its dominance in international capital flows to the region. However, bank loans have increased significantly during 20042008, due to buoyant lending from mother banks in Western European countries, attracted by relatively high interest rates and policies encouraging credit.

CEEC have received considerable amounts of FDI inflows during the last two decades, as reflected in the increased of the stock of FDI, from basically zero at the beginning of the nineties to almost $60 \%$ of the region’s GDP by 2010. Countries like the Czech Republic, Poland and Hungary, which were among the first to proceed with structural reforms and provided economic stability relatively early on, were also the first recipients of FDI. Regarding the composition of FDI inflows, M\&A had a significant share during the nineties, essentially due to the privatization process (see Figure 1 in appendix). However, despite some privatization contracts being conditional on the implementation of an investment program, only a small part of the privatization revenues were destined to financing capital formation. Adversely, after 2000, an increasing share of FDI inflows was represented by greenfield investment. Figure 1 in appendix illustrates the composition of FDI inflows by entry mode for each of the 10 countries in our sample.

In section 5 of the paper we look into detail into the structure of FDI inflows, with potentially different implications for the substitution/complementarity of FDI to domestic investment. To this end, we separate FDI into greenfield investment and mergers and acquisition (M\&A). As data on the value of cross-border mergers and acquisitions is collected by UNCTAD, we construct our series of M\&A using different editions of the World Investment Report. Finally, we compute greenfield investment as the difference between total FDI flows and M\&A, approach used by Calderon et al. (2004), Wang and Wong (2009) and Eren and Zhuang (2015).

Finally, in order to assess the interaction between FDI and local investors through the financial market, we use a composite indicator of financial market development, called $F I N \_D E V$. This indicator is computed as a simple average of three sub-indicators : banking sector reform and interest rate liberalization, capital market development and foreign exchange market development. These indicators are provided by the European Bank for Reconstruction and Development in its series of transition indicators. The values of this 
composite indicators thus continuously range from 1 to 4 , where 1 means a minimal financial development, and 4 indicates a developed financial market, to the standards of advanced economies $^{11}$. Table 11 in appendix presents the average values of this indicator for each of the countries in the sample. We note that financial markets are more developed in Hungary and Poland, while they are the least developed in Romania and Bulgaria.

\section{Results}

The first results of our estimations are presented in Table 2. They suggest that investment process has indeed a consistent structural component, as the autoregressive coefficient is strongly significant. Its value (between 0.506 and 0.743 ) indicates the lack of unit root, as confirmed by additional previous stationarity tests.

Among the classical determinants of investment, the interest rate is not significant in any of the estimated models. However, all three existing studies that considered the interest rate (Mody and Murshid, 2005; Agrawal, 2005; Wang, 2010) obtained inconclusive results. Adversely, economic growth appears to be a significant factor driving investment, through the accelerator mechanism and by creating expectations about the future economic prospects. Among the control variables, only the net terms of trade have a significant influence on investment. Increasing external competitiveness in the tradable sector indicates relatively cheaper imports. Since most capital goods are imported, it thus becomes easier for entrepreneurs to purchase capital goods, which stimulates local investment.

Among our variables of interest, only FDI and foreign loans have a significant contribution to capital formation. The fact that portfolio investment does not affect capital formation has been also proven by Mody and Murshid (2005), Bosworth and Collins (1999) and Mileva (2008). As the main purpose of portfolio investors is to obtain financial gains through dividends, they prefer profit distribution to profit reinvestment. Portfolio investment in the CEEC had

\footnotetext{
${ }^{11}$ The detailed description of the three specific indicators that compose FIN_DEV is the following. Banking reform and interest rate liberalization: 1 indicates little progress beyond the establishment of a dual banking system, while 4 indicates full compliance of banking regulation of the Bank for International Settlements and the existence of competitive banking services. Capital market development: 1 indicates low progress, while 4 indicates full convergence of regulations on transactions with financial assets to the IOSCO standards and the full development of non-bank financial intermediation. The development of the foreign exchange market: 1 indicates limited access to foreign currency and restrictions on imports and exports, while 4 indicates total convertibility of the currency and the full liberalization of the current account, with the removal of all restrictions on foreign currency transactions.
} 
essentially a diversification purpose and was not interested in productive investment. Moreover, portfolio investments are relatively volatile compared to other international capital flows, therefore associated with a degree of uncertainty, which may harm productive investment. Additionally, financial markets in the region are underdeveloped, which limits the potential contribution of portfolio investment to capital formation.

Table 2. The contribution of capital flows to domestic capital formation in CEEC

\begin{tabular}{|c|c|c|c|c|}
\hline $\begin{array}{l}\text { Dependent variable } \\
\text { GFCF }\end{array}$ & (1) & (2) & (3) & (4) \\
\hline L.GFCF & $\begin{array}{c}0.743^{* * *} \\
(0.086)\end{array}$ & $\begin{array}{c}0.572^{* * *} \\
(0.114)\end{array}$ & $\begin{array}{c}0.563 * * * \\
(0.117)\end{array}$ & $\begin{array}{c}0.506^{* * *} \\
(0.120)\end{array}$ \\
\hline L.GROWTH & $\begin{array}{c}0.077 \\
(0.059)\end{array}$ & $\begin{array}{l}0.106^{*} \\
(0.052)\end{array}$ & $\begin{array}{l}0.112^{*} \\
(0.060)\end{array}$ & $\begin{array}{c}0.174^{* * * *} \\
(0.063)\end{array}$ \\
\hline INTEREST & $\begin{array}{c}0.014 \\
(0.044) \\
\end{array}$ & $\begin{array}{c}0.003 \\
(0.043) \\
\end{array}$ & $\begin{array}{l}-0.034 \\
(0.051) \\
\end{array}$ & $\begin{array}{c}0.031 \\
(0.061) \\
\end{array}$ \\
\hline FDI & $\begin{array}{c}0.379 * * * \\
(0.117)\end{array}$ & $\begin{array}{l}0.297 * * \\
(0.121) \\
\end{array}$ & $\begin{array}{l}0.275^{* *} \\
(0.118) \\
\end{array}$ & $\begin{array}{c}0.285^{* *} \\
(0.117) \\
\end{array}$ \\
\hline PORTF & $\begin{array}{c}0.046 \\
(0.084)\end{array}$ & $\begin{array}{c}0.050 \\
(0.079)\end{array}$ & $\begin{array}{c}0.041 \\
(0.078)\end{array}$ & $\begin{array}{c}0.102 \\
(0.084)\end{array}$ \\
\hline LOANS & $\begin{array}{c}0.340 * * * \\
(0.122)\end{array}$ & $\begin{array}{c}0.361 * * * \\
(0.114)\end{array}$ & $\begin{array}{c}0.257 * * \\
(0.125)\end{array}$ & $\begin{array}{c}0.292 * * \\
(0.125)\end{array}$ \\
\hline TERMS_TRADE & & $\begin{array}{l}9.423^{* *} \\
(4.584)\end{array}$ & $\begin{array}{l}13.973 * * * \\
(5.305)\end{array}$ & $\begin{array}{c}18.539 * * * \\
(5.539)\end{array}$ \\
\hline VOLAT & & $\begin{array}{l}-0.018 \\
(0.026)\end{array}$ & $\begin{array}{l}-0.019 \\
(0.027)\end{array}$ & $\begin{array}{c}-0.004 \\
(0.028)\end{array}$ \\
\hline DEV_M2 & & $\begin{array}{c}0.041 \\
(0.076)\end{array}$ & $\begin{array}{c}0.048 \\
(0.074)\end{array}$ & $\begin{array}{c}0.040 \\
(0.074)\end{array}$ \\
\hline W & & & $\begin{array}{c}0.098 \\
(0.062)\end{array}$ & $\begin{array}{c}0.085 \\
(0.063)\end{array}$ \\
\hline TRADE_OPEN & & & & $\begin{array}{c}0.020 \\
(0.025)\end{array}$ \\
\hline trend & $\begin{array}{c}-0.159 * * * \\
(0.051)\end{array}$ & $\begin{array}{c}-0.163^{* * *} \\
(0.048)\end{array}$ & $\begin{array}{c}-0.167 * * * \\
(0.051)\end{array}$ & $\begin{array}{c}-0.225^{* *} \\
(0.091)\end{array}$ \\
\hline Observations & 139 & 139 & 128 & 128 \\
\hline Instruments & 11 & 11 & 12 & 13 \\
\hline Sargan p-value & 0.312 & 0.396 & 0.507 & 0.677 \\
\hline AR2 test $p$-value & 0.407 & 0.474 & 0.668 & 0.825 \\
\hline
\end{tabular}

Note: Estimates are made using GMM Arellano Bond. Standard errors are reported in brackets. *, **, and $* * *$ refers to the $10 \%, 5 \%$ and $1 \%$ significance levels. The null hypothesis of the Arrelano Bond AR (2) test is no second order autocorrelation in the residuals. The Sargan test for validity of instruments has for null hypothesis the exogeneity of the instrument set.

The coefficient of foreign loans is comparable to that of FDI. The banking sector in CEEC is dominated by foreign subsidiaries and most foreign loans are basically loans from parent 
banks to their subsidiaries. Due to the low level of local savings, foreign banks have found an profitable way to capitalize savings collected in developed countries by transferring it to their subsidiaries in Central and Eastern Europe. This has definitely lead to a local credit boom. Finally, the development of major infrastructure projects during the transition period frequently made recourse to external financing, therefore explaining the contribution of loans to capital formation.

Focusing on the role of FDI in capital accumulation, we can first notice, as expected, a positive overall contribution. We note a relatively stable coefficient, ranging between 0.275 0.297. Therefore, a 1\% of GDP increase in FDI inflows leads to an increase of approximately $0.28 \%$ of gross fixed capital formation. The values obtained are much smaller than 1 , thus confirming a short term crowding-out effect on domestic investment, due to increased competition by foreign firms.

Based on these short term coefficients presented in Table 2, the theoretical assumptions outlined in Table 1 are reduced to just two: substitution and creative destruction. In order to validate one of these two hypothesis, we need to compute a long-term impact of FDI on domestic investment. The dynamic structure of equation (2) allows the compute the long-term elasticity of local investment to FDI, based on the convergence to the steady rate of investment $^{12}$. Therefore, this elasticity is given by $\beta_{L}(F D I)=\frac{\beta_{S}(F D I)}{1-\alpha}$. This approach was originally used by Borensztein et al. (1998) and extended by Agosin and Mayer (2000) and Agosin and Machado (2005). Later on, it was applied by most empirical studies interested in the crowding-out effect (Mody and Murshid, 2005; Mileva, 2008; Misun and Tomšík, 2002). Moreover, studies that find a complementary relationship between FDI and domestic investment report high values of this elasticity term (between 2.4-2.6 for Misun and Tomšík, 2002,and a long-term elasticity larger than 3 for Mody and Murshid, 2005). The significance

\footnotetext{
${ }^{12}$ Long term elasticities are computed based on the following principle: If $Y_{t}=\alpha Y_{t-1}+\beta X_{t}$, than long term equilibrium means that $\mathrm{Y}$ and $\mathrm{X}$ do not significantly differ from their stationary levels: $Y_{t-1}=Y_{t}=Y$ and $X_{t}=X$. Thus we have $Y=\alpha Y+\beta X$ or $Y(1-\alpha)=\beta X$. Finally, we can write $Y=\frac{\beta}{1-\alpha} X$. The marginal effect of $\mathrm{X}$ on $\mathrm{Y}$ equals $\frac{\partial Y}{\partial X}=\frac{\beta}{1-\alpha}$.
} 
of this long term elasticity can be tested relatively straightforward through a Wald test ${ }^{13}$. Given that all coefficients were found to be significant, we comparing the elasticity to 1 by using the same Wald test. These results can be found in Table 3.

Table 3. Long run elasticity of local investment to FDI

\begin{tabular}{|l|c|c|c|c|}
\hline \hline & $(1)$ & $(2)$ & $(3)$ & $(4)$ \\
\hline Long run elasticity to FDI & $0.802^{* *}$ & $0.694^{* *}$ & $0.628^{*}$ & $0.578^{*}$ \\
& $(0.393)$ & $(0.345)$ & $(0.326)$ & $(0.337)$ \\
\hline Wald test Ho: $\beta_{\mathrm{FDI}}=1$ & $\mathrm{~F}(1,142)=0.25$ & $\mathrm{~F}(1,129)=0.79$ & $\mathrm{~F}(1,117)=1.30$ & $\mathrm{~F}(1,116)=1.57$ \\
$(p$-value $)$ & $(0.616)$ & $(0.375)$ & $(0.256)$ & $(0.212)$ \\
\hline \hline
\end{tabular}

Source: the Wald test in this table are based on coefficients from Table 2.

We observe that the long-term elasticity ranges between 0.578 and 0.802 , indicating the persistence of a long run substitution effect of FDI to domestic investment. These values are also higher than short-term FDI coefficients, indicating that that the crowding-out effect decreases in intensity over time. Nevertheless, the long run elasticity is never higher than 1 , suggesting that even in the long run FDI does not seem to stimulate domestic investment.

Although values under unity, the Wald test cannot however reject the hypothesis of long run coefficients equal to 1 . We are cautious in interpreting these results, as p-values are quite low (between 0.21-0.25). The standard errors associated with the computed long run elasticities are relatively high, generating a wider confidence interval and making it difficult to reject the null hypothesis of unit coefficient. With the introduction of additional explanatory variables, the value of the FDI coefficient decreases, as it long-run elasticity. Moreover, we believe that the omission of some relevant determinants of investment could explain the very high elasticities obtained by some of the previous literature (Misun and Tomšík, 2002; Mody and Murshid, 2005).

As a partial conclusion, we can say that there is definitely a substitution effect between FDI and local investment. This effect decreases over time, without however revealing a long-term complementary relationship. If we were to return to the theoretical assumptions in Table 1 , our results validates the $\mathrm{H} 1$ hypothesis of both short and long term substitution. Local entrepreneurs, crowded out due to increased competitive pressures and weak institutional support, are never fully replaced on the market even after some years. The negative effect on

\footnotetext{
${ }^{13}$ The null hypothesis of the Wald test would be that the long run elasticity equals zero, thus indicating no long term effect of FDI on local investment.
} 
domestic investment is likely to take place both within the same sector and in upstream sectors. If we consider downstream sectors, inputs of better quality could potentially generate a stimulating effect on investment. This effect is however less important compared to the substitution of local investors and needs a longer time to materialize.

Based on results so far, we argue that the most plausible hypothesis in CEEC is the crowdingout effect of FDI on domestic investment. In order to deepen the analysis, we proceed with two original contributions. We first separate FDI according to their entry mode (greenfield and M\&A). Second, we investigate the nature of the interaction of foreign and domestic investors (on the real or on the financial market) .

\section{Entry mode of FDI and impact on domestic investment. M\&A versus greenfield FDI}

The literature generally treats FDI as a homogeneous capital flow. However, different types of FDI can have potentially different implications for the relationship with domestic investors. We thus separate FDI according to its entry mode in greenfield investment and mergers and acquisitions, as this distinction is useful to provide information on the motivation of foreign investors. Harms and Méon (2011) showed that the effect of M\&A on economic growth was weaker than that of greenfield investment, while Wang and Wong (2009) even found a negative impact on growth. For CEEC, Ersen and Zhuang (2015) found no significant independent contribution from neither greenfield nor M\&A to economic growth. To our knowledge, this is the first study to take this distinction into account in the context of the FDI - domestic investment relationship.

We will briefly discuss why we expect a different relationship between the two types of FDI and domestic investment. In the case of greenfield FDI, the foreign affiliate represents a completely new firm, with no existing capital stock. The acquisition of productive means in this case consists of a net addition to the capital formation. Adversely, M\&A basically consist of an ownership change of existing assets, without an immediate addition to the capital stock. For this reason, the impact greenfield FDI on local capital accumulation is expected to be higher than for M\&A (Agosin and Machado, 2005; Mileva, 2008). Some studies argue that foreign takeovers can in certain conditions be followed by investments in the upgrading of production process, which would not have been done in the absence of a foreign investor 
(Agosin, 1996; UNCTAD, 1999). UNECA (2006 ) even suggests that, in the long run, there seems to be no difference in capital accumulation between greenfield investment and M\&A.

The literature has often suggested that greenfield FDI is expected to have a coefficient of 1 when explaining total investment, as it reflects an accounting fact (Mileva, 2008). In other words, the value of greenfield investment would immediately be reflected in gross capital formation. However, we keep in mind that FDI is essentially a financial flow (equity, reinvested earnings or intra- group loans), not real flow. There is thus no guarantee that these flows finance (fully or partially) fixed capital investment, even if FDI is to be greenfield . We can off course assume that most financial transfers reflect asset acquisition, but they can also finance current expenditures. Finally, if the potential for fixed capital formation is greater for greenfield FDI than M\&A, the relationship is far from deterministic. It is thus difficult at the aggregate level to estimate the extent to which these flows finance acquisition of fixed assets.

If we analyze the entry mode of foreign investors and their objectives, M\&A seem to be more oriented towards the local market. These companies operate in existing sectors, with stable trade linkages with local companies. The post-acquisition period is normally devoted to a productivity improvement process, though modernization and technical upgrading. The risk of an adverse competition effect on local investment in those sectors seems high. Most greenfield FDI, on the other hand, are export oriented and do not directly compete with local suppliers. To the extent that FDI uses local inputs, greenfield investment may even stimulate new investment from domestic suppliers.

Although the implications of the two types of FDI for domestic investment are far from being clear, the related empirical literature is almost non-existent. Calderon et al. (2004) are among the few authors separating foreign investment in greenfield and M\&A, while studying the causal effect of FDI on gross capital formation and economic growth. They conclude that both greenfield investments and M\&A cause gross capital formation in industrialized, as well as developing countries during the 1987-2001 period. Although intuitive, this result is on one hand interesting as it also covers M\&A. On the other hand, the study does not provide any information about relationship between the two types of FDI and domestic investment, with potential consequences for the structure of the capital stock.

While seeking to compensate this caveat of the literature, we extend the analysis in section 4 by separating FDI flows in greenfield investment (GREEN) and mergers and acquisitions 
$(M \& A)$. The results of these new estimates are found in Table 4. If aggregate FDI had a positive, though bellow unity effect on capital formation, its two components seem to have a different contributions to capital accumulation. As expected, greenfield investment significantly contributes to capital accumulation, while M\&A have no relevant impact.

Table 4. Entre mody of FDI and the impact on domestic investment

\begin{tabular}{lcc}
\hline \hline & $(1)$ & $(2)$ \\
\hline L.GFCF & $0.555^{* * *}$ & $0.441^{* *}$ \\
& $(0.123)$ & $(0.182)$ \\
L.GROWTH & $0.102^{*}$ & 0.102 \\
& $(0.061)$ & $(0.086)$ \\
INTEREST & 0.006 & 0.005 \\
& $(0.048)$ & $(0.067)$ \\
\hline FDI & $0.309^{* *}$ & \\
& $(0.131)$ & \\
M\&A & & 0.313 \\
& & $(0.203)$ \\
GREEN & & $0.721^{* * *}$ \\
& & $(0.250)$ \\
\hline PORTF & 0.066 & 0.245 \\
& $(0.096)$ & $(0.154)$ \\
LOANS & $0.361^{* * *}$ & $0.196^{*}$ \\
& $(0.138)$ & $(0.118)$ \\
VOLAT & -0.018 & -0.001 \\
& $(0.027)$ & $(0.039)$ \\
TERMS_TRADE & $10.448^{* *}$ & $8.839^{*}$ \\
& $(4.902)$ & $(5.021)$ \\
Observations & & \\
Instruments & 129 & 124 \\
Sargan $p$-value & 10 & 11 \\
AR2 test $p$-value & 0.860 & 0.978 \\
\hline \hline
\end{tabular}

Note: The dependant variable is gross fixed capital formation GFCF. Estimates are made using GMM Arellano Bond. Standard errors are reported in brackets. *, **, and *** refers to the $10 \%, 5 \%$ and $1 \%$ significance levels. A trend is included in the estimation, though not reported. The null hypothesis of the Arrelano Bond AR (2) test is the absence of second order autocorrelation in the residuals. The Sargan test for validity of instruments has the null hypothesis of exogeneity of the instrument set.

Table 5. Long run elasticities of domestic investment to the types of FDI

\begin{tabular}{|l|c|c|c|}
\hline \hline & $\begin{array}{c}\text { Total FDI } \\
(F D I)\end{array}$ & $\begin{array}{c}\text { Mergers\&acquisitions } \\
(M \& A)\end{array}$ & $\begin{array}{c}\text { Greenfield } \\
(G R E E N)\end{array}$ \\
\hline Long run elasticity & $0.695^{*}$ & 0.560 & $1.289^{* *}$ \\
of GFCF to FDI & $(0.359)$ & $(0.402)$ & $(0.582)$ \\
\hline \hline
\end{tabular}

Source: the elasticities are computed based on coefficients from Table 4. 
We also note that the coefficient for greenfield investment is still bellow unity, though more than double the coefficient for aggregate FDI. This is a confirmation that greenfield investment has a stronger crowding-out effect on domestic investment, compared to other forms of FDI, essentially M\&A. Their transformation in real physical investment is thus quite obvious. M\&A, on the other hand, as we intuitively argued, have no significant effect on capital formation, being more a financial transaction than an actual productive investment.

Long-term elasticities give us some additional information regarding the relationship between FDI and domestic investment. Table 5 contains the values of these computed elasticities. The elasticity of GFCF to total FDI flows confirms our previous results, being higher than the short run coefficient and ranging around 0.7. For greenfield investment though we get a significant long-run elasticity larger than $1\left(\beta_{\text {GREEN }}^{L}=1.289\right)$. The implications of this result are quite important. Unlike aggregate FDI, which persists in a long term substitution with domestic investment, greenfield FDI develops a complementary relationship in the long run. This indicates the validation of our creative destruction hypothesis (H2 in Table 1), with an initial crowding-out effect, followed by a long term crowding-in.

We think this result has mainly two explanations. On the one hand, the export orientation of greenfield investment avoids a too strong competition for local producers ${ }^{14}$. On the other hand, greenfield investments develop trade linkages with local suppliers, thus stimulating capital formation in upstream sectors. This crowding-in effect definitely takes some time to materialize, as shown by the long run elasticity. We can thus state that the short-term crowding-out effects mainly occurs within the same sector, while the long run crowding-in effect is expected to occur especially in upstream sectors. Finally, M\&A have no long run effect on gross fixed capital formation.

Based on these results, which show that the nature and purpose of the two types of FDI are quite different, we wonder whether the mechanisms of interaction between FDI and domestic investors could also be different. The next section is devoted to this additional analysis.

\footnotetext{
${ }^{14}$ Competition may also take place on foreign markets, but it is clearly less important than the domestic market.
} 


\section{Financial development and the relationship between FDI and domestic investment}

As stated in section 2, the interaction between FDI and domestic investment may occur either through the goods market or the financial market. The first case is specific to investors operating within the same sector, while the second case concerns interaction between foreign and domestic investors regardless of the sector in which they operate.

Agosin and Machado (2005), referring to the interaction on the real market, suggest that if FDI follows the existing industrial pattern of the host economy, the effect will most likely be a crowding-out of local producers due to increased competitive pressure. A crowding-in effect is thus expected if foreign investors target underdeveloped or new local industries, with a limited risk of replacing existing producers.

In the case of real market crowding-out, some local producers are displaced due to the higher efficiency of FDI. However, the net impact on national wealth can be positive as it is the most efficient firms remain on the market, thus generating higher value added. Government intervention should therefore only be needed to alleviate the potential risks related to the denationalization of certain industries (UNCTAD, 2000) and the creation of foreign affiliates enclaves.

To the extent that the crowding-out takes place on the financial market, banks' preference for foreign companies could restrict access to finance for domestic investors. Foreign affiliates are known to enjoy a higher solvency due to financial guarantees provided by the MNE. Moreover, in the context of limited financial resources, increased loan demand could result in higher interest rates. If the crowding-out of local investors takes places through the financial market, the net effect would be a decrease in national wealth. Government intervention in this case is needed, with measures that facilitate access to credit for local investors.

Identifying the mechanism by which FDI crowds out domestic investors is essential to create appropriate economic policies and assess their effectiveness. Although the two types of interaction convey different policy implications, there is no study yet to empirically address this duality. In order to fill in this void, we seek to isolate the interaction between FDI and local investors on the financial market, the rest being interpreted as real market interaction. As we cannot directly measure financial interaction, we argue, in line with Razin et al. (1999), that the phenomenon should be all the more present as local financial markets are developed. 
The argument lies in the effectiveness of deep financial markets to redistribute capital, possibly at lower interest rates. To this end, we use a composite indicator of financial market development and analyze its interaction with FDI in the capital accumulation process. A detailed description of this indicators is available in the Data section.

Since M\&A are financial transactions only involving ownership transfer of existing assets, the potential for the funds to feed into the local financial market is much higher than for greenfield investments. This can have two possible effects ${ }^{15}$. On the one hand, larger liquidity may cause a decrease in the interest rate, thus facilitating access to finance for local investors (Harrison et al., 2004). Razin et al. (1999) also states that capital entering the country through M\&A is not spent immediately, but forms a financial pool that benefits local entrepreneurs. On the other hand, if these flows are relatively large compared to the size of the local financial market, they can lead to exchange rate appreciation (UNCTAD, 2000), thus eroding export competitiveness and diverting investment in exporting sectors.

In the case of greenfield investments, on the other hand, a significant part of the invested capital will be used for capital goods purchase. As most often these goods are imported (UNCTAD, 2003), the increase in the domestic capital supply would be reduced. Even if capital goods are bought locally and the foreign exchange resources of local producers will thus increase, their further transfer to the financial system is not guaranteed. Local producers may in fact decide, as a result of increased demand, to use the funds for investment, possibly through imported capital goods.

Based on these arguments and the results from the previous section, we expect mergers and acquisitions to have a high potential in influencing domestic investment through the financial market. Consequently, we construct two additional interaction terms: $M \& A^{*} F I N \_D E V$ and GREEN*FIN_DEV. The results of this new set of estimates are found in Table 6. In this case, we cannot compute the long term elasticities, and more precisely their p-values, due to the complexity introduced by interaction terms.

\footnotetext{
${ }^{15}$ There is also a third scenario, even though unlikely. The shareholders of local firms taken over by foreign investors may use the funds thus obtained to invest in other sectors of the economy. Agosin (2008) argues, however, that this phenomenon is almost nonexistent, as most shareholders prefer to buy other financial assets (local or foreign) rather than to make real investment.
} 
Results suggest that the interaction of aggregate FDI inflows with financial development has no significant impact on capital accumulation. We interpret this result as an indication of no significant interaction of foreign and domestic investors on the financial market. The FDI coefficient keeps its significance and subunit value under, confirming the crowding-out effect on the real market. Out of the two types of interactions, the competition on the real market clearly the dominating relationship between FDI and local investment.

Table 6. Financial development and the effect of FDI on domestic investment

\begin{tabular}{|c|c|c|c|}
\hline & (1) & (2) & (3) \\
\hline L.GFCF & $\begin{array}{c}0.568 * * * \\
(0.121)\end{array}$ & $\begin{array}{c}0.678 * * * \\
(0.182)\end{array}$ & $\begin{array}{l}0.446^{*} \\
(0.248)\end{array}$ \\
\hline L.GROWTH & $\begin{array}{c}0.123 * * \\
(0.061)\end{array}$ & $\begin{array}{c}0.082 \\
(0.068)\end{array}$ & $\begin{array}{c}0.074 \\
(0.122)\end{array}$ \\
\hline INTEREST & $\begin{array}{c}0.012 \\
(0.049) \\
\end{array}$ & $\begin{array}{l}-0.004 \\
(0.052)\end{array}$ & $\begin{array}{c}0.152 \\
(0.129) \\
\end{array}$ \\
\hline FDI & $\begin{array}{l}0.518^{*} \\
(0.293)\end{array}$ & & \\
\hline M\&A & & $\begin{array}{c}-0.202 \\
(0.128)\end{array}$ & \\
\hline GREEN & & & $\begin{array}{l}1.492^{*} \\
(0.859)\end{array}$ \\
\hline PORTF & $\begin{array}{c}0.012 \\
(0.088)\end{array}$ & $\begin{array}{l}-0.082 \\
(0.102)\end{array}$ & $\begin{array}{c}0.069 \\
(0.180)\end{array}$ \\
\hline LOANS & $\begin{array}{c}0.351^{* *} \\
(0.137)\end{array}$ & $\begin{array}{c}0.486^{* * *} \\
(0.146)\end{array}$ & $\begin{array}{c}0.558 * * \\
(0.275)\end{array}$ \\
\hline VOLAT & $\begin{array}{l}-0.000 \\
(0.037)\end{array}$ & $\begin{array}{l}-0.044 \\
(0.027)\end{array}$ & $\begin{array}{c}0.021 \\
(0.060)\end{array}$ \\
\hline TERMS_TRADE & $\begin{array}{c}10.228 * * \\
(4.889)\end{array}$ & $\begin{array}{c}9.630 \\
(5.892)\end{array}$ & $\begin{array}{l}10.299 \\
(9.673)\end{array}$ \\
\hline FIN_DEV & $\begin{array}{c}-1.748 \\
(1.763)\end{array}$ & $\begin{array}{l}-0.464 \\
(1.827)\end{array}$ & $\begin{array}{l}-2.037 \\
(3.108)\end{array}$ \\
\hline FDI*FIN_DEV & $\begin{array}{l}-0.025 \\
(0.022)\end{array}$ & & \\
\hline M\&A*FIN_DEV & & $\begin{array}{c}0.782^{* *} \\
(0.389)\end{array}$ & \\
\hline GREEN*FIN_DEV & & & $\begin{array}{c}-2.167 \\
(1.406)\end{array}$ \\
\hline Observations & 136 & 121 & 126 \\
\hline Instruments & 12 & 12 & 12 \\
\hline Sargan $p$-value & 0.429 & 0.912 & 0.913 \\
\hline AR2 test $p$-value & 0.482 & 0.484 & 0.519 \\
\hline
\end{tabular}

Note: The dependent variable is gross fixed capital formation GFCF. Estimates are made using GMM Arellano Bond. Standard errors are reported in brackets. *, **, and *** refers to the $10 \%, 5 \%$ and $1 \%$ significance levels. A trend is included in the estimation, though not reported. The null hypothesis of the Arrelano Bond AR (2) test is the absence of second order autocorrelation in the residuals. The Sargan test for validity of instruments has the null hypothesis of exogeneity of the instrument set. 
M\&A are individually not significant, but their interaction with financial market development drives a crowding-in effect on domestic investment. We interpret this result as evidence of complementarity between M\&A and local investment through the financial market. The competition induced by firms taken over by foreign investors is not strong enough to reduce or cancel previously planned investment projects, in the context of strong integration of joint ventures into local trade networks. While not directly addressing capital accumulation, Eren and Zhuang (2015) also confirmed that a developed financial system was needed in order to exploit the growth benefits from M\&As in CEEC, whereas it had no modulating role in what concerns greenfield FDI.

The interaction between financial market development and greenfield investment is at the significance limit $(t$-stat $=-1.54)$, while having a negative sign. Though not particularly significant, greenfield investments seem to compete local investors on the financial market. Additional to the direct capital injection from the parent company, foreign affiliates actually have various financing sources for their investment projects. In particular, they can borrow on local (and international) capital markets, flows unaccounted for in the FDI metric. The World Investment Report (1999) actually showed that multinationals in emerging countries invest about a third more than the actual value of FDI inflows.

We can thus conclude that the interaction between greenfield investment and domestic investment essentially takes place on the real market, and gives rise to a crowding-out of local investors. On the contrary, the interaction between M\&A and domestic investment occurs only on the financial market, with a generally crowding-in effect on domestic investment. The net effect ultimately on the share M\&A in total FDI flows and the importance of M\&A flows to the local supply of foreign currency.

\section{Discussion and conclusions}

Theoretical studies suggest that FDI may crowd-out domestic investment in the short term, while leading to a long-run complementarity. In order to test this hypothesis, we extend the existing empirical framework of Agosin and Machado (2005) by first including some additional determinants of investment virtually ignored in the literature. Second, we investigate the individual effects of greenfield investment and M\&A on domestic investment. 
Finally, we provide some information on the nature of the interaction between foreign and local investors, on the real and on the financial market, with different implications for the dynamics of local investment.

Our empirical analysis on Central and Eastern Europe confirms a short term crowding-out effect of FDI on domestic investment. The negative effect is decreasing over time, as foreign affiliates develop trade linkages with local suppliers, without however turning into a crowding-in effect.

The entry mode of foreign investors seems to influence the impact of FDI on domestic investment. Our results suggest that greenfield investments are the only ones significantly increasing the capital stock, while M\&A remain mostly a financial flows with no immediate contribution to capital accumulation. Moreover, greenfield FDI show an initial substitution of local investors, tending towards a long-term complementarity, due to linkages with local suppliers and knowledge spillovers.

Finally, we investigated the extent to which the interaction between foreign and local investors takes place on real market or the financial market. Our results confirm that M\&A stimulate domestic investment by facilitating access to finance. Countries with developed financial markets (Hungary, Poland, Estonia) benefit more from this crowding-in effect due to their ability to effectively redistribute resources where needed. We can thus conclude that the real market interaction is specific to greenfield investment, generally crowding-out local investors. Additionally, the financial market interaction seems to be specific to M\&A, with a general crowding-in effect.

We ask ourselves whether state intervention is needed in this case and in what sense? The aim of any policy measure would be maximizing the investment rate and mitigating the negative crowding-out effect. On one hand, a liberal opinion would be against state intervention, as the crowding-out is the result of a competitive market mechanism, with an net positive effect on welfare. Consumers will benefit from better quality products, while foreign affiliates will in turn accelerate value added creation through higher productivity. On the other hand, local firms exiting the market will cause unemployment and a long-term risk of a denationalization of some industries. Consequently, a selection of FDI could be useful : greenfield investment to be preferred to M\&A because it leads to a crowding-in of domestic investment in the long run; FDI entry to be encouraged in underdeveloped industries, export-oriented FDI to be 
favored, provided a minimum local content. However, practical implementation of such measures is likely to fail if governments focus on a restrictive policy. We suggest a relative liberal policy in attracting foreign investors, combined with an incentive scheme to target certain types of FDI. Moreover, in the case of a crowding-out effect, authorities can also use fiscal levers to stimulate reinvestment of capital released by the cessation of activities. 


\section{APPENDIX}

Table 7. Descriptive statistics of main variables

\begin{tabular}{|l|l|l|l|l|l|}
\hline \hline \multicolumn{1}{|c|}{ Variable } & \multicolumn{1}{c|}{ Mean } & St.dev. & \multicolumn{1}{c|}{ Min } & \multicolumn{1}{c|}{ Max } & \multicolumn{1}{c|}{ N } \\
\hline GFCF & 23.2 & 5.1 & 6.0 & 36 & 210 \\
FDI & 4.4 & 4.1 & -1.2 & 29.5 & 200 \\
PORTF & 0.35 & 3.13 & -16.2 & 13.1 & 179 \\
LOANS & 0.81 & 3.27 & -18.4 & 14.2 & 182 \\
GROWTH & 2.0 & 6.7 & -31.3 & 12.8 & 206 \\
INTEREST & 5.5 & 7.0 & -15.6 & 32.7 & 171 \\
\hline \hline
\end{tabular}

Table 8. Testing the exogeneity of explanatory variables

\begin{tabular}{|l|l|l|}
\hline \hline $\begin{array}{l}\text { Potentially endogenous } \\
\text { variables }\end{array}$ & $\begin{array}{l}\text { Davidson MacKinnon } \\
\text { exogeneity test (F test) }\end{array}$ & $p$-value \\
\hline FDI & 3.80 & 0.0247 \\
PORTF & 4.61 & 0.0116 \\
LOANS & 4.17 & 0.0176 \\
\hline \hline
\end{tabular}

Note: The null hypothesis of the Davidson-MacKinnon (1993) test is the exogeneity of explanatory variables.

Table 9. Correlation table of different instruments with the dependent variable

\begin{tabular}{|l|r|r|r|r|r|}
\hline & \multicolumn{1}{|l|}{$\begin{array}{l}\text { REGIONAL } \\
\text { FLOWS }\end{array}$} & $\begin{array}{l}\text { FIN } \\
\text { OPEN }\end{array}$ & US & \multicolumn{1}{l|}{$\begin{array}{l}\text { RERAT } \\
\text { RER }\end{array}$} \\
\hline GFCF & 1.00 & & & & \\
\hline REGIONAL_FLOWS & 0.159 & 1.00 & & & \\
\hline FIN_OPEN & 0.148 & 0.699 & 1.00 & & \\
\hline US & 0.056 & -0.602 & -0.426 & 1.00 & \\
\hline VOLAT_RER & -0.063 & 0.081 & 0.234 & -0.030 & 1.00 \\
\hline
\end{tabular}


Table 10. Difference in the Sargan test of exogeneity of instruments

\begin{tabular}{|l|c|c|c|c|}
\hline \hline Instruments & FDI & PORTF & LOANS & TOTAL \\
\hline REGIONAL FLOWS & 0.753 & 0.959 & 0.810 & 0.652 \\
FIN_OPEN & 0.341 & 0.396 & 0.491 & 0.336 \\
US & 0.441 & 0.249 & 0.399 & 0.556 \\
VOLAT_RER & 0.598 & 0.666 & 0.534 & 0.581 \\
\hline \hline
\end{tabular}

Note: We individually considered each of the three endogenous variables as instrumented by the corresponding instruments, while in the last columns we simultaneously instrument all three variable FDI, PORTF, LOANS.

Table 11. The composite indicator of financial development (FIN_DEV)

\begin{tabular}{|l|c|c|c|c|}
\hline \hline FIN_DEV & $\begin{array}{c}\text { Average value } \\
1990-2010\end{array}$ & 1990 & 2010 & $\begin{array}{c}\text { Progress from } \\
1990 \text { to 2010 }\end{array}$ \\
\hline Bulgaria & 2.92 & 1.3 & 3.7 & 2.4 \\
\hline Czech Rep & 3.29 & 1 & 4 & 3 \\
\hline Estonia & 3.28 & 1 & 4 & 3 \\
\hline Hungary & 3.64 & 2 & 4 & 2 \\
\hline Latvia & 3.05 & 1 & 3.7 & 2.7 \\
\hline Lithuania & 3.02 & 1 & 3.8 & 2.8 \\
\hline Poland & 3.47 & 2 & 4 & 2 \\
\hline Romania & 2.79 & 1 & 3.6 & 2.6 \\
\hline Slovakia & 3.14 & 1 & 3.6 & 2.6 \\
\hline Slovenia & 3.18 & 1.7 & 3.6 & 1.9 \\
\hline \hline
\end{tabular}

Source: own calculation based on three transition indicators provided by the EBRD. 
Figure 1. Greenfield FDI versus M\&A (1990-2010)
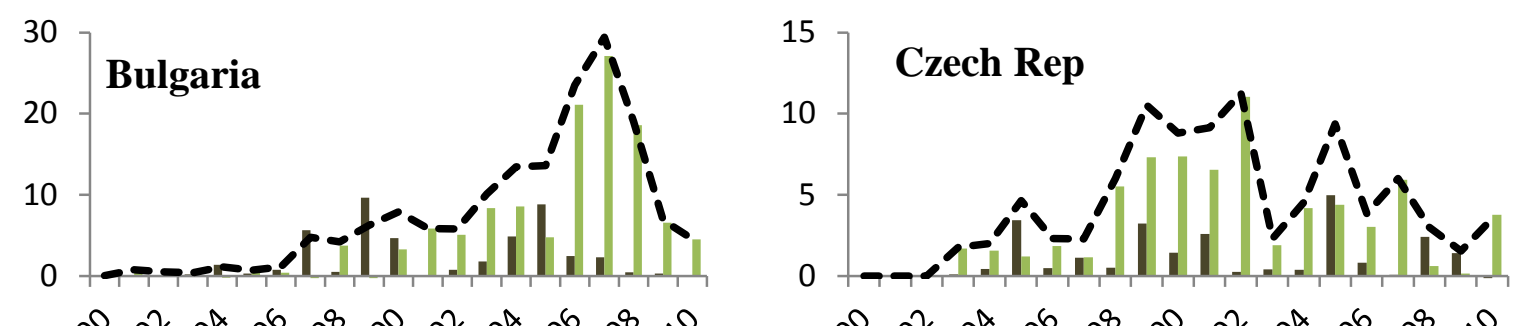

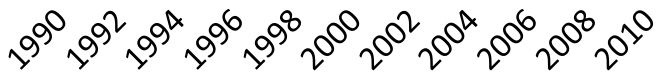
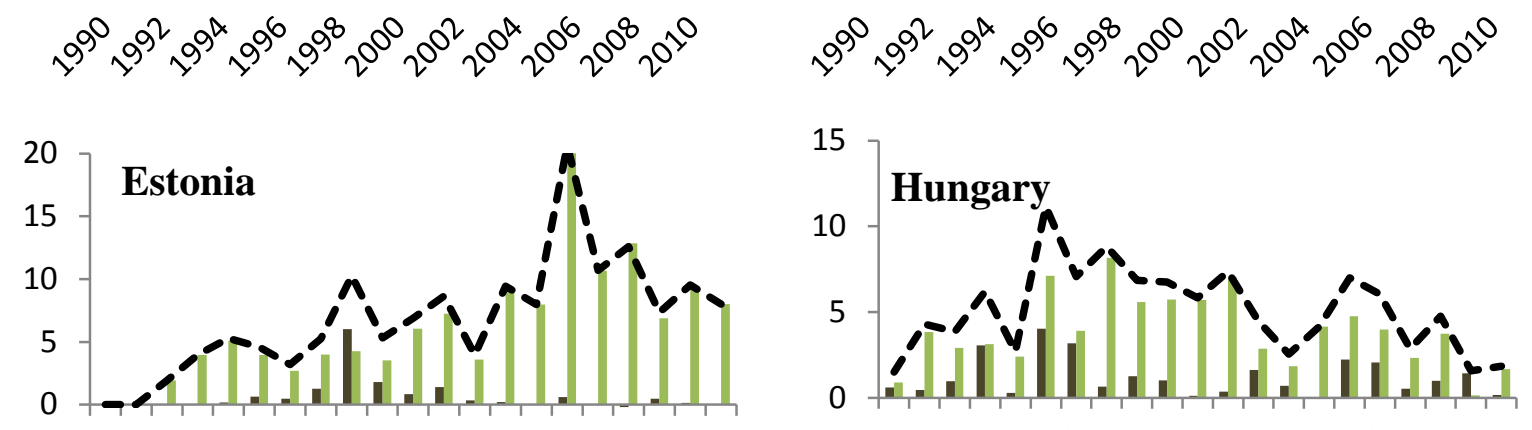

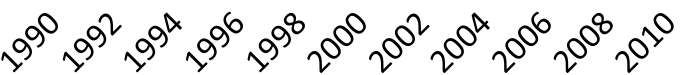

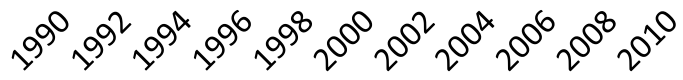
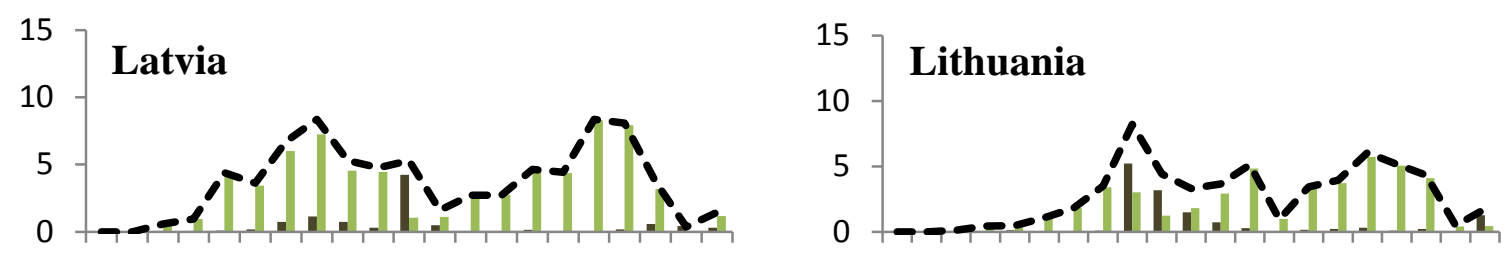

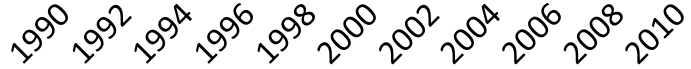

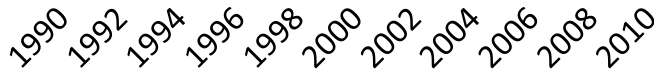
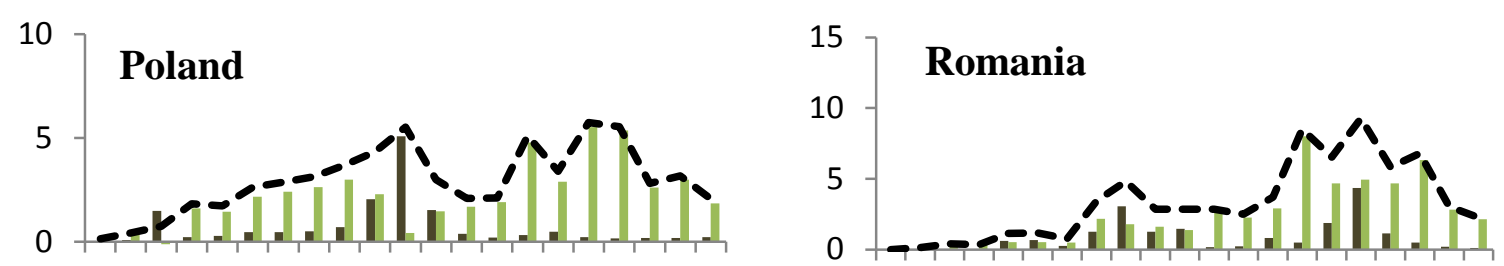

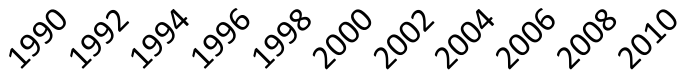

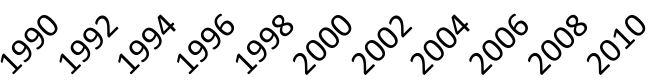
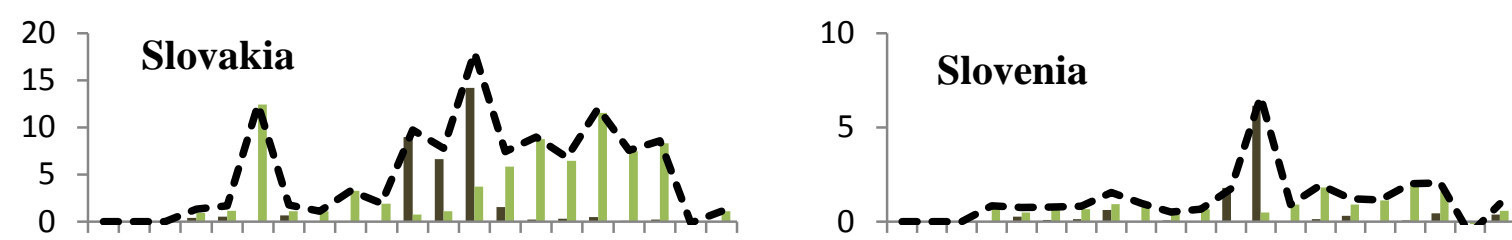

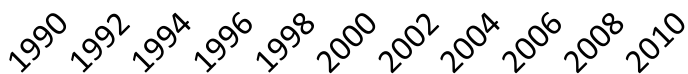

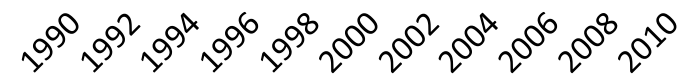

Greenfield (\% GDP)

M\&A (\%GDP) -.... Total FDI (\%GDP)

Source: data comes from UNCTAD, WIR 2011 (FDI) and UNCTADStat (GDP). M\&A refer to crossborder merges and acquisitions, as reported by the country of the seller. Greenfield investment is the difference of total FDI flows and M\&A. 


\section{References}

1. Agosin M. (1996). "El retorno de la inversión extranjera a América Latina”. In: Agosin MR, ed. Inversión extranjera directa en América Latina: su contribución al desarrollo. Santiago and Mexico City, Fondo de Cultura Económica.

2. Agosin Manuel, Machado Roberto, (2005). "Foreign Investment în Developing Countries: Does it Crowd în Domestic Investment?," Oxford Development Studies, Taylor and Francis Journals, vol. 33(2), pages 149-162.

3. Agrawal, Pradeep. (2005) "Foreign Direct Investment in South Asia: Effects on Growth and Local Investment", in Edward M. Graham, editor, Multinationals and Foreign Investment in Economic Development. London, Palgrave/Macmillan. pp. 94-118.

4. Aitken, Brian and Harrison, Ann (1999), "Do Domestic firms benefit from Foreign Direct Investment? Evidence from Venezuela”, American Economic Review nr. 89(3)

5. Arellano, M., and O. Bover. (1995). Another look at instrumental variables estimation of error-component models. Journal of Econometrics 68: 29-51.

6. Arellano, M., S. Bond. (1991), "Some tests of specification for panel data: Monte Carlo evidence and an application to employment equations". The Review of Economic Studies, 58. p. $277-297$

7. Barrios, S., H. Görg and E. Strobl, (2005), Foreign direct investment, competition and industrial development in the host country, European Economic Review 49, 1761-1784

8. Blonigen Bruce A. \& Wang Miao, (2004). "Inappropriate Pooling of Wealthy and Poor Countries in Empirical FDI Studies," NBER Working Papers 10378.

9. Borensztein, E., De Gregorio, J., Lee, J, (1998). "How does Foreign Direct Investment Affect Economic Growth?” Journal of International Economics 45: 115-135

10. Bosworth, B. P.; Collins, S. M. (1999) "Capital Flows to Developing Economies: Implications for Saving and Investment," Brookings Papers on Economic Activity, 1, p. 143-69

11. Calderon, Cesar \& Loayza, Norman \& Serven, Luis, (2004). "Greenfield foreign direct investment and mergers and acquisitions - feedback and macroeconomic effects,"Policy Research Working Paper Series 3192, The World Bank

12. Cardoso, E. A.; Dornbusch, R. B, (1989). "Foreign Private Capital Flows," in: H. B. Chenery, T. N. Srinivasan eds., Handbook of Development Economics, Vol. 2, Amsterdam: Elsevier

13. Carkovic, M. and Levine, R. (2005) "Does Foreign Direct Investment Accelerate Economic Growth?” in Th. H. Moran, E.D. Graham, and M. Blomström, eds., Does Foreign Direct Investment Promote Development? Washington, DC: Institute for International Economics, pp. 195-220.

14. de Mello Jr., Luiz R.(1997) "Foreign direct investment in developing countries and growth: A selective survey', Journal of Development Studies, 34: 1, 1- 34

15. de Mello, L.R. (1999), "Foreign direct investment- led growth: evidence from time series and panel data', Oxford Economic Papers, 51(1), 133-51 
16. Eichengreen, B. (2004), "Productivity Growth, the New Economy, and Catching Up". Review of International Economics, 12: 243-245

17. Eren Mesut \& Zhuang Hong, (2015). "Mergers and Acquisitions Versus Greenfield Investment, Absorptive Capacity, and Economic Growth: Evidence from 12 New Member States of the European Union”, Eastern European Economics, 53, p. 99-123.

18. Harrison, A. E., Love, I. and M. S. McMillan (2004). "Global capital flows and financing constraints”. Journal of Development Economics, 75. pp. 269-301

19. Hayakawa, K. (2009). “A simple efficient instrumental variable estimator for panel AR(p) models when both $\mathrm{N}$ and T are large”. Econometric Theory 25: 873-90.

20. Hunya Gabor, 2000, "Integration through Foreign Direct Investment", Cheltenham: Edward Elgar, London

21. Jude, Cristina (2015). Technology Spillovers from FDI. Evidence on the Intensity of Different Spillover Channels, The World Economy, http://dx.doi.org/10.1111/twec.1233

22. Kose, M. A., E. Prasad, K. Rogoff and S.-J. Wei (2006). "Financial globalization: $a$ reappraisal”. IMF Working Paper, 06/189.

23. Kumar N., Pradhan J. P. (2002). "Foreign direct investment, externalities and economic growth in Developing Countries: some empirical explorations and implications for WTO Negotiations on Investment", RIS Discussion Paper 27 (New Dehli: Research and Information System for the Nonaligned and other Developing Countries).

24. Liu Zhiqiang, (2008) Foreign direct investment and technology spillovers: Theory and evidence, Journal of Development Economics, 85, pp. 176-193

25. Markusen, James R. \& Venables, Anthony J., (1999). "Foreign direct investment as a catalyst for industrial development," European Economic Review, Elsevier, vol. 43(2), pages 335-356, February

26. Mileva Elitza, (2008), "The impact of capital flows on domestic investment in transition economies," Working Paper Series 871, European Central Bank

27. Mišun Jan \& Tomšík Vladimír, (2002). "Foreign direct investment in Central Europe does it crowd in domestic investment?," Prague Economic Papers, University of Economics, Prague, vol. 2002(1).

28. Mody, A. and A. P. Murshid (2005). "Growing up with capital flows". Journal of International Economics, 65/2005. pp. 249-266.

29. Morrissey, Oliver. Udomkerdmongkol, Manop. (2012) “Governance, Private Investment and Foreign Direct Investment in Developing Countries”, World Development, vol. 40, issue 3, pages 437-445

30. Razin, A., Sadka, E., \& Yuen, C. (1999). "Excessive FDI under asymmetric information”. NBER Working Paper 7400, Cambridge.

31. Romer, Paul, 1993. "Idea gaps and object gaps in economic development," Journal of Monetary Economics, Elsevier, vol. 32(3), pages 543-573, December.

32. Solow, Robert M. (1956). "A contribution to the theory of economic growth“. Quarterly Journal of Economics, 70, 65-94. 
33. Wang Miao, (2010). "Foreign direct investment and domestic investment in the host country: evidence from panel study," Applied Economics, Taylor \& Francis Journals, vol. 42(29), pages 3711-3721.

34. Wang, Miao, M. C. Sunny Wong. (2009) "What Drives Economic Growth? The Case of Cross-Border M\&A and Greenfield FDI Activities,” Kyklos, 62(2), 316-330

35. UNCTAD (2003), World Investment Report 2003 - FDI Policies for Development: National and International Perspectives, Geneva

36. UNCTAD (1999), World Investment Report 1999 - Foreign Direct Investment and the Challenge of Development, Geneva

37. UNECA - United Nations Economic Commission for Africa (2006) - "Capital Flows and Development Financing in Africa", Addis Ababa, Ethiopia 